\title{
ANALISIS MANAJEMEN SUMBER DAYA MANUSIA STRATEGIK PADA DINAS KEBERSIHAN KOTA BEKASI
}

\author{
Ika Widiastuti \\ Universitas Krisnadwipayana
}

\begin{abstract}
Abstrak
Sumber daya manusia menjadi faktor utama dalam suatu organisasi yang dibangun berdasarkan kepentingan kebutuhan dan pelaksanaan. Terbatasnya sumber daya manusia tidak terlepas dari kurangnya perencanaan strategik dalam mengelola keberlanjutan suatu organisasi dan kurangnya dalam membuat analisis SWOT. Setiap organisasi tidak lepas dari manajemen sumber daya manusia (MSDM) Strategik karena MSDM Strategik dapat menjadi sebuah inovasi organisasi untuk mencapai tujuan yang diinginkan organisasi. Penelitian ini bertujuan adalah untuk memperoleh temuan deskriptif : kekuatan, kelemahan, peluang dan ancaman pada Dinas Kebersihan Kota Bekasi. Penelitian ini merupakan jenis penelitian deskriptif kualitatif. Metode pengumpulan data menggunakan teknik pencatatan dokumen, wawancara, dan observasi. Data dianalisis dengan menggunakan analisis deskriptif kualitatif. Hasil penelitian ini menunjukkan bahwa kekuatan, kelemahan, peluang dan ancaman (SWOT) telah dilakukan dengan cukup baik dan benar dengan mempertimbangkan lingkungan internal namun harus lebih memperhatikan lingkungan eksternal organisasi.
\end{abstract}

Kata Kunci: Manajemen Sumberdaya Manusia Strategik.

\begin{abstract}
Human resources become the main factor in an organization that is built based on the interests of needs and implementation. Limited human resources cannot be separated from the lack of strategic planning in managing the sustainability of an organization and the lack of making a SWOT analysis. Every organization cannot be separated from Strategic Human Resource Management (HRM) because Strategic HRM can be an organizational innovation to achieve the desired goals of the organization. The purpose of this research is to obtain descriptive findings: strengths, weaknesses, opportunities and threats at Bekasi City Sanitation Department. This research is a descriptive qualitative research. The data collection method uses document recording techniques, interviews, and observations. Data were analyzed using qualitative descriptive analysis. The results of this study indicate that the strengths, weaknesses, opportunities and threats (SWOT) have been done quite well and correctly by considering the internal environment but must pay more attention to the external environment of the organization.
\end{abstract}

Keywords: Strategic Human Resource Management.

\section{A. PENDAHULUAN}

Sumber daya manusia menjadi faktor utama dalam suatu organisasi yang dibangun berdasarkan kepentingan kebutuhan dan pelaksanaan. Terbatasnya sumber daya manusia tidak terlepas dari kurangnya perencanaan strategik dalam mengelola keberlanjutan suatu organisasi dan kurangnya dalam membuat analisis SWOT. Maka saat ini manajemen strategik menjadi hal yang sangat penting dan menjadi fokus dalam meningkatkan dari segi 
ARTIKEL

kuantitas dan kualitasnya. Beberapa strategi, disusun untuk dapat menuntun agar menimbulkan perubahan yang cukup penting, sehingga dapat dikatakan peran strategik sumber daya manusia setara dalam pengelolaan manajemen keuangan, pemasaran, produksi dan informasi.

Pentingnya strategi sumber daya manusia bagi organisasi diantaranya melibatkan semua pihak dalam organisasi, konsentrasi pada kelangsungan organisasi dengan tujuan dan menciptakan nilai tambah, strategi organisasi meliputi seluruh jangkauan dan kedalaman organisasi, mengarahkan pada perubahan dan mencakup organisasi dan lingkungannya, pusat pengembangan bagi keunggulan kompetitif yang keberlanjutan, pengembangan strategi yang sangat krusial untuk memacu keberhasilan.

Perusahaan memiliki berbagai sumber daya, namun sumber daya manusia (SDM) menempati posisi strategis diantara sumber daya lainnya. Tanpa SDM, sumber daya yang lain tidak bisa dimanfaatkan apalagi dikelola untuk menghasilkan suatu produk. Banyak perusahaan yang menganggap SDM adalah aset organisasi yang paling penting, karena SDM yang menggerakkan dan membuat sumber daya lainnya bekerja. Menyadari pentingnya peran SDM dalam kegiatan perusahaan, maka hendaknya perusahaan perlu mengelola sumber daya manusia sebaik mungkin, karena kunci sukses suatu perusahaan bukan hanya pada keunggulan teknologi dan tersedianya dana, tapi sektor manusianya. Segala tindakan dan keputusan yang dibuat dalam perusahaan adalah semata-mata untuk mencapai tujuan perusahaan, untuk itu diperlukan manusia-manusia yang handal yang mampu menjalankan tindakan dan kemudi perusahaan agar dapat selalu survive. Perencanaan dan pengelolaan yang efektif atas sumber daya manusia yang ada pada perusahaan sangat diperlukan, sehingga segala keahlian dan tenaga yang diperlukan perusahaan dapat digunakan sepenuhnya dengan hasil yang efektif dalam peranan tenaga kerja saat ini dan dapat fleksibel terhadap tanggung jawab yang lain di luar peran utama tenaga kerja tersebut dalam perusahaan.

Pengelolaan SDM yang baik akan sangat menguntungkan bagi perusahaan, karena akan menghemat biaya, memperbaiki kinerja, mempercepat pencapaian tujuan, dan sekaligus akan menciptakan hubungan yang baik antara tenaga kerja dengan perusahaan. Perusahaan untuk dapat mencapai keuntungan seperti di atas, maka harus ada hubungan timbal balik antara tenaga kerja dan perusahaan, hubungan itu dapat berupa pemenuhan harapan dan kebutuhan tenaga kerja serta pemenuhan standar kinerja yang diharapkan oleh perusahaan. SDM perlu dikelola melalui strategi-strategi SDM yang tepat, agar perusahaan dapat memaksimalkan pertumbuhannya dan mencapai tujuan dalam jangka pendek dan jangka panjang secara optimal. Perusahaan dapat memaksimalkan keunggulan bersaingnya dengan berpusat pada SDM, melalui efisiensi dari para karyawan.

Setiap organisasi tidak lepas dari manajemen sumber daya manusia (MSDM) Strategik karena MSDM Strategik dapat menjadi sebuah inovasi organisasi untuk mencapai tujuan yang diinginkan organisasi. Untuk menghadapi persaingan di masa kini, sangatlah penting bagi seorang manajer untuk berpikir strategi. MSDM Strategik merupakan serangkaian keputusan dan tindakan yang digunakan untuk merumuskan dan melaksanakan strategi, yang memungkinkan kesesuaian antara perusahaan dan lingkungannya sehingga dapat mencapai tujuan organisasi. Perumusan strategik mencakup perencanaan, pengambilan keputusan untuk mencapai tujuan perusahaan, dan membuat rencana strategi spesifik. 
Dalam perencanaan MSDM Strategik perlu memperhatikan beberapa langkah utama untuk mengembangkan suatu organsasi yang berkualitas, yaitu pernyataan misi yang baik sebagai tujuan yang mendasar dan unik untuk dapat membedakannya dengan organisasi lain. MSDM Strategik juga harus menganalisis lingkungan internal dan eksternal yang digunakan untuk mengetahui kekuatan, kelemahan, peluang dan ancaman yang dimiliki oleh organisasi. Perumusan MSDM Strategik bertujuan untuk mencapai visi melalui misi dan tujuan yang diinginkan oleh organisasi dalam bersaing.

MSDM Strategik mempertimbangkan implikasi strategi organisasi pada seluruh sistem SDM dalam organisasi dengan cara menerjemahkan tujuan-tujuan organisasi kedalam sistemsistem MSDM yang spesifik. Keberhasilan MSDM sangat ditentukan oleh dukungan yang jelas pada misi dan strategi organisasi. Saat ini sangat penting memahami SDM dalam menghadapi persaingan global. Manajemen organisasi atau yang baik harus mengetahui dengan pasti bagaimana kinerja dapat ditingkatkan. Banyak organisasi yang memformulasikan dan mengimplementasikan MSDM Strategik, namun jarang sekali perusahaan melakukan evaluasi dan pengendalian kinerja karyawannya.

Permasalahan sampah di Indonesia sangat kompleks. Bagaimana tidak, dikota-kota besar seperti Jakarta saja sampah masih saja berserakan dimana-mana. Kementerian Pekerjaan Umum (PU), Kementerian Negara Lingkungan Hidup (KNLH), Kementerian Perencanaan Pembangunan Nasional, Pemerintah Provinsi DKI Jakarta, Pemerintah Kota Bekasi, Pemerintah Kota Denpasar, dan Pemerintah Kabupaten Gianyar dinilai belum efektif dalam melakukan pengelolaan sampah perkotaan karena kelemahan dalam aspek kebijakan dan pelaksanaan pelayanan persampahan.

Persoalan sampah di Kota Bekasi menjadi sorotan. Jumlah pertumbuhan penduduk yang relatif cepat di wilayah perkotaan menimbulkan beragam permasalahan seperti meningkatnya kasus kriminalitas dan penurunan kualitas sarana dan prasarana yang signifikan hingga permasalahan sampah. Selain itu, tingkat konsumsi masyarakat yang cenderung tinggi dan sistem pengelolaan sampah yang belum mapan menjadi masalah utama bagi warga di wilayah perkotaan tak terkecuali Kota Bekasi.

Pemerintah Kota Bekasi belum efektif dalam melakukan pengelolaan dan pengolahan sampah perkotaan karena kelemahan dalam aspek kebijakan dan pelaksanaan pelayanan persampahan. Hal tersebut mengakibatkan kinerja pengelolaan sampah belum mendukung pencapaian sasaran pembangunan persampahan nasional yang telah ditetapkan dalam Rencana Pembangunan Jangka Menengah (RPJM) Nasional. Selain itu, pelayanan pengangkutan sampah yang dilakukan oleh Dinas Kebersihan Kota Bekasi juga belum optimal.

Permasalahan banyaknya sampah di Kota Bekasi juga dikarenakan terbatasnya lahan di tempat pembuangan akhir (TPA). Pengelolaan sampah di TPA aktif dan bekas TPA tidak berwawasan lingkungan (environmental friendly) mengakibatkan lingkungan di sekitar TPA menjadi tercemar sehingga menurunkan kualitas lingkungan dan kesehatan masyarakat sekitar, serta membahayakan keselamatan masyarakat. Permasalahan ini disebabkan Kota Bekasi tidak menjalankan kewajibannya untuk melakukan pembinaan dan pengawasan terhadap ketaatan penanggung jawab usaha dan/atau kegiatan atas ketentuan yang ditetapkan dalam peraturan perundang-undangan di bidang perlindungan dan pengelolaan lingkungan hidup dan melakukan penegakan hukum lingkungan hidup pada tingkat 
provinsi/kabupaten/kota. Pengelolaan kebersihan tidak terlepas dari adanya dukungan dan sinergitas manajemen sumber daya manusia strategik, sehingga dapat diwujudkan pelayanan pengelolaan kebersihan yang partisipatif, holistik dan berkelanjutan.

Pemeriksaan kinerja atas pengelolaan sampah perkotaan dilaksanakan pada Pemerintah Kota Bekasi. Pemerintah Kota Bekasi belum memiliki standar pelayanan minimal (SPM) pengelolaan sampah, yang mengakibatkan tidak terjaminnya hak masyarakat untuk menerima suatu pelayanan dasar sesuai dengan mutu tertentu, dan tidak adanya indikator kinerja yang terukur dalam mengevaluasi kinerja operator pengelolaan sampah daerah tersebut. Pemerintah Kota Bekasi tidak mencapai sasaran dan target sesuai master plan atau rencana strategik pengelolaan sampah daerahnya. Hal tersebut mengakibatkan tujuan pengelolaan sampah seperti pengurangan timbunan sampah ke TPA, peningkatan jangkauan dan kualitas pelayanan persampahan, peningkatan SDM yang profesional dalam mengelola kebersihan kota, serta peningkatan partisipasi masyarakat dalam mengelola sampah dan kebersihan kota tidak tercapai sesuai dengan rencana yang ditetapkan.

Dinas Kebersihan Kota Bekasi menetapkan strategi pembangunan dengan memfokuskan upaya-upaya yang mampu meningkatkan kemakmuran rakyat sebagai upaya untuk menciptakan keadaan Kota Bekasi yang bersih, hijau, sejahtera, adil, dan lestari Sebagai satuan kerja yang memiliki tugas pokok melaksanakan kewenangan otonomi daerah dalam rangka pelaksanaan tugas kebersihan memiliki tantangan dan permasalahan pokok yang dihadapi dalam pelaksanaan program kerja di Dinas Kebersihan Kota Bekasi. Kebersihan Kota Bekasi merupakan penjabaran lebih lanjut dan sistematis atas visi, misi dan program Dinas Kebersihan kedalam tujuan, strategi, kebijakan dan program, kegiatan, alokasi dana indikatif dan sumber pendanaan yang dirumuskan dalam MSDM. Namun sampai saat ini MSDM Strategik pada Dinas Kebersihan Kota Bekasi belum mengevaluasi kinerja SDM yang semestinya harus dilakukan oleh Dinas Kebersihan Kota Bekasi guna meningkatkan kinerja pada perusahaan. Menurut Wheelen dan Hunger (2001: 46), Manajemen sumber daya manusia strategik harus melakukan kontrol (evaluasi) dan tindak lanjut agar organisasi selalu mengawasi strategi SDM yang ada sehingga dapat bersaing. Dengan adanya permasalahan di atas maka diperlukan strategik yang baik dalam pengelolaan manajemen sumber daya manusia yaitu dengan membuat analisis SWOT sehingga kita dapat mengetahui kekuatan, kelemahan, peluang, ancaman suatu organisasi.

Tujuan penelitian yang ingin dicapai adalah untuk memperoleh temuan deskriptif sebagai berikut: untuk mengetahui dan memahami analisis SWOT pada Dinas Kebersihan Kota Bekasi.

\section{B. TINJAUAN PUSTAKA}

\section{Manajemen Sumber Daya Manusia Strategik}

Palinggi (2008: 109) menyatakan, manajemen sumber daya manusia merupakan kegiatan yang berkaitan dengan perencanaan, pengambilan keputusan, pengimplementasian, dan pengendalian sumber daya manusia yang meliputi strategi, kiat, dan tindakan serta penerapan dari keputusan-keputusan tersebut yang langsung menyangkut atau mempengaruhi sumber daya manusia yang bekerja di dalam perusahaan. Keputusan-keputusan manajemen tersebut merupakan pelaksanaan fungsi sumber daya manusia. 
Menurut Mabey (1998: 112), Manajemen sumber daya manusia strategik merupakan proses pengelolaan sumber daya manusia organisasi dari sisi strategik organisasi yang mengaitkan pengelolaan sumber daya manusia dengan strategi organisasi. Selain itu menurut Dessler (2000: 123), Manajemen sumber daya manusia strategik menghubungkan manajemen sumber daya manusia dengan peran strategis, tujuan untuk meningkatkan kinerja bisnis dan mengembangkan budaya organisasi, serta mendorong inovasi dan fleksibilitas.

Strategik manajemen sumber daya manusia menurut Zainal (2015:64) adalah suatu pertalian antara manajemen sumber daya manusia dengan tujuan dan sasaran strategi agar dapat memperbaiki kinerja dan mengembangkan budaya organisasi sehingga dapat mendorong dalam berkreasi, berinovasi dan lebih fleksibel. Dengan kata lain strategi dalam mengelola pola penyebaran sumber daya manusia yang terencana dan tindakan untuk dapat meningkatkan kemampuan organisasi agar tercapai tujuannya.

Manajemen sumber daya manusia strategik memerlukan perhatian dan dukungan besar dari seluruh sumber daya manusia yang dimiliki organisasi karena berkaitan dengan peran strategis sebagai upaya untuk meningkatkan kinerja sumber daya manusia. Sedangkan Amstrong (2003: 98) menyatakan, manajemen sumber daya manusia strategik merupakan pendekatan untuk membuat keputusan pada skema dan rencana organisasi berkaitan dengan hubungan pekerjaan dan kebijakan serta pelaksanaan perekrutan, pelatihan, pengembangan, manajemen kinerja, imbalan dan hubungan karyawan.

Berdasarkan definisi di atas dapat disimpulkan bahwa manajemen sumber daya manusia strategik merupakan proses pengelolaan sumber daya manusia dalam suatu organisasi yang secara menyeluruh dengan mengkaitkan hubungan pekerjaan dan kebijakan serta pelaksanaan perekrutan, pelatihan, pengembangan, manajemen kinerja, imbalan dan hubungan karyawan untuk mencapai tujuan strategis dalam rangka memperbaiki kinerja organisasi.

\section{Analisis SWOT}

Menurut Wheelen dan Hunger (2001:193), analisis situasi merupakan awal proses perumusan strategi. SWOT adalah akronim untuk kekuatan (strenghts), kelemahan (weakness), peluang (opportunities), dan ancaman (threats) dari perusahaan yang semuanya merupakan faktor-faktor strategis. Lingkungan eksternal berisi variabel peluang dan ancaman (oppoturnities and threats) yang berada di luar organisasi dan bukan merupakan hal yang dapat dikontrol oleh pimpinan organisasi dalam jangka waktu dekat. Lingkungan internal organisasi terdiri dari variabel kekuatan dan kelemahan (strenghts and weaknesses) yang berada dalam tubuh organisasi itu sendiri dan biasanya tidak dalam kontrol pimpinan organisasi dalam waktu dekat. Yang termasuk dalam variabel ini adalah struktur, budaya, dan sumber daya organisasi.

Selain itu menurut Tunggal (2001:74), SWOT adalah akronim untuk kekuatan (strenghts) dan kelemahan (weakness) internal suatu perusahaan dan peluang (opportunities) dan ancaman (threats) lingkungan yang dihadapi perusahaan. Analisa SWOT merupakan identifikasi yang sistematis dari faktor-faktor ini dan strategi yang menggambarkan pedoman yang terkait antara mereka.

Heinz Weihrich (1982) menjelaskan bahwa matriks SWOT (Strengths-WeaknessesOpportunities-Threats) adalah sebuah alat yang sangat penting dalam membantu manajer 
untuk mengembangkan empat strategi : strategi SO (strengths-opportunities), strategi WO (weaknesses-opportunities), strategi ST (strengths-threats), dan strategi WT (weaknessesthreats). Lebih lanjut Fred R. David (2011: 178) menjelaskan bahwa mencocokkan faktor internal dan eksternal adalah hal yang paling sulit dalam membuat matriks SWOT karena membutuhkan penilaian yang baik.

Perumusan MSDM Strategik seringkali ditunjukkan sebagai perencanaan strategis atau jangka panjang. Proses perumusan MSDM Strategik menjelaskan pengembangan visi, misi, tujuan, strategi dan kebijakan perusahaan. Agar ini tercapai, pembuatan MSDM Strategik harus menganalisis faktor-faktor strategis perusahaan (kekuatan, kelemahan, peluang dan ancaman). Sedangkan menurut Jogiyanto (2005: 46), SWOT digunakan untuk menilai kekuatan-kekuatan dan kelemahan-kelemahan dari sumber-sumber daya yang dimiliki perusahaan dan kesempatan-kesempatan eksternal dan tantangan-tantangan yang dihadapi."

Selanjutnya Rangkuti (2006), Analisis SWOT adalah identifikasi berbagai faktor secara sistematis untuk merumuskan strategi perusahaan. Analisa ini dilakukan pada logika yang dapat memaksimalkan kekuatan dan peluang secara bersamaan dapat meminimalkan kelemahan dan ancaman. Analisis SWOT merupakan analisis terhadap empat elemen yaitu: (1) kekuatan (strenght) merupakan karakteristik positif internal yang dapat dieksploitasi organisasi unruk meraih sasaran kinerja strategi; (2) kelemahan (weakness) merupakan karakteristik internal yang dapat menghalagi atau melemahkan kinerja organisasi; (3) peluang (opportunity) merupakan karakteristik dari lingkunga eksternal yang memiliki potensi untuk membantu organisasi meraih atau melampaui sasaran strateginya; dan (4) ancaman (threat) merupakan karakteristik dari lingkungan eksternal yang dapat mencegah organisasi meraih sasaran strategi yang telah ditetapkan.

Menurut Wheelen dan Hunger (2001), Matriks SWOT (dikenal juga dengan TOWS) menggambarkan bagaimana manajemen dapat mencocokkan peluang dan ancaman eksternal yang dihadapi perusahaan dapat disesuaikan dengan kekuatan dan kelemahan yang dimilikinya untuk menghasilkan empat rangkaian altenatif strategis. Matriks TOWS digunakan untuk mengidentifikasi cara-cara alternatif sehingga organisasi dapat menggunakan kekuatan-kekuatan khusus untuk menggunakan kesempatan atas peluang atau untuk menghindari ancaman, dan mengatasi kelemahan.

Selanjutnya menurut Rangkuti (2006), alat yang dipakai untuk menyusun faktorfaktor strategis perusahaan adalah matriks SWOT. Matriks ini menggambarkan bagaimana peluang dan ancaman eksternal (EFAS) yang dihadapi perusahaan dapat disesuaikannya dengan kekuatan dan kelemahan internal (IFAS) yang dimilikinya. Matriks ini dapat menghasilkan empat (4) set kemungkinan alternatif strategi. Cara membuat matriks SWOT adalah dengan menggunakan faktor-faktor strategis eksternal maupun internal sebagaimana telah dijelaskan dalam tabel EFAS dan IFAS, yaitu dengan mentransfer peluang dan ancaman dari tabel EFAS serta mentransfer kekuatan dan kelemahan dari tabel IFAS kedalam sel yang sesuai dalam matriks SWOT.

\section{METODE}

Penelitian ini merupakan penelitian deskriptif kualitatif. Subjek penelitian pada penelitian ini adalah manajemen strategik yakni SWOT. Sedangkan objek penelitian ini 
adalah Dinas Kebersihan Kota Bekasi. Jenis data yang digunakan dalam penelitian ini adalah data kualitatif.

Sumber data dalam penelitian ini adalah data primer dan data sekunder. Data primer adalah data yang diperoleh secara langsung dari sumbernya yang dalam penelitian ini yang menjadi sumber adalah manajer Dinas Kebersihan Kota Bekasi. Data yang didapat yaitu situasi SWOT dan strategi-strategi yang dilakukan instansi. Sedangkan data sekunder adalah data yang diperoleh dengan menelaah literatur lain yang mendukung penelitian yang berupa buku-buku. Pengumpulan data dalam penelitian ini dilakukan dengan menggunakan teknik pencatatan dokumen, wawancara, dan observasi.

\section{HASIL DAN PEMBAHASAN}

Berdasarkan hasil penelitian yang dilakukan maka diperoleh data SWOT Dinas Kebersihan Kota Bekasi seperti yang tampak pada tabel berikut:

Tabel 1. Hasil Penelitian MSDM Strategik pada Dinas Kebersihan 2004

\begin{tabular}{|c|l|l|c|l|}
\hline No. & $\begin{array}{c}\text { Komponen } \\
\text { MSDM } \\
\text { Strategik }\end{array}$ & \multicolumn{1}{|c|}{ Unsur } & Nilai & Kategori \\
\hline 1. & SWOT & Faktor Internal dan Faktor Eksternal & 3 & $\begin{array}{l}\text { Cukup } \\
\text { baik }\end{array}$ \\
\hline 2. & $\begin{array}{l}\text { Formulasi } \\
\text { MSDM } \\
\text { Strategik }\end{array}$ & $\begin{array}{l}\text { Visi, misi, tujuan, sasaran, strategic dan arah } \\
\text { kebijakan }\end{array}$ & 5 & $\begin{array}{l}\text { Sangat } \\
\text { baik }\end{array}$ \\
\hline 3. & $\begin{array}{l}\text { Implementasi } \\
\text { MSDM } \\
\text { Strategik }\end{array}$ & $\begin{array}{l}\text { Program, kegiatan, sasaran, indikator kinerja, } \\
\text { target kinerja dan anggaran }\end{array}$ & 5 & $\begin{array}{l}\text { Sangat } \\
\text { baik }\end{array}$ \\
\hline 4. & $\begin{array}{l}\text { Evaluasi dan } \\
\text { pengendalian } \\
\text { MSDM } \\
\text { sStrategik }\end{array}$ & $\begin{array}{l}\text { Program, target kinerja, realisasi capaian dan } \\
\text { umpan balik }\end{array}$ & 4 & Baik \\
\hline & \multicolumn{1}{|c|}{ Rata-rata } & $\mathbf{4}$ & Baik \\
\hline
\end{tabular}

Sumber: Hasil Diolah

Berdasarkan Tabel 1 mengenai SWOT, maka dapat diungkapkan bahwa dalam analisis SWOT pada Dinas Kebersihan Kota Bekasi menunjukkan organisasi yang mempunyai kondisi internal yang kuat dan lingkungan eksternal yang belum mendukung yang berarti berada pada kategori cukup baik karena kekuatan manajemen sumber daya manusia strategik sudah optimal, kelemahan manajemen sumber daya manusia strategik mampu ditangani, peluang manajemen sumber daya manusia strategik yang belum baik, dan belum optimalnya menangani ancaman manajemen sumber daya manusia strategik. Hal ini dapat dilihat dari proses analisis yang dilakukan pada lingkungan internal dan lingkungan eksternal organisasi untuk menentukan strategi.

Berdasarkan hasil penelitian yang telah dilakukan menunjukkan bahwa kekuatan, kelemahan, peluang dan ancaman pada Dinas Kebersihan Kota Bekasi berada pada kategori cukup baik, artinya organisasi mempunyai kondisi internal yang kuat dan lingkungan 
eksternal yang belum mendukung karena kekuatan manajemen sumber daya manusia strategik sudah optimal, kelemahan manajemen sumber daya manusia strategik mampu ditangani, peluang manajemen sumber daya manusia strategik yang belum baik, dan belum optimalnya menangani ancaman manajemen sumber daya manusia strategik. Secara keseluruhan manajemen sumber daya manusia strategik pada Dinas Kebersihan Kota Bekasi berada pada kategori yang baik dilihat dari SWOT yang cukup baik,

\section{E. KESIMPULAN}

Berdasarkan hasil penelitian dan pembahasan yang telah dilakukan, maka dapat disimpulkan bahwa kekuatan, kelemahan, peluang dan ancaman (SWOT) pada Dinas Kebersihan Kota Bekasi telah dilakukan dengan cukup baik dan benar dengan mempertimbangkan lingkungan internal namun harus lebih memperhatikan lingkungan eksternal organisasi.

\section{DAFTAR PUSTAKA}

Amstrong, \& Kotler. (2000). Manajemen Sumber Daya Manusia Strategik. Jakarta: Penerbit PT. Indeks Gramedia.

Bangun ,W. (2012). Manajemen Sumber Daya Manusia. Erlangga: Jakarta.

Barthos, B. (2009). Manajemen sumber daya manusia: Jakarta: Bumi aksara.

Certo \& Peter. 1991. Strategic Management: Concepts and Application. New York: McGraw.

Darmadi, H. (2011). Metode Penelitian Kualitatif. Bandung: Alfabeta.

Dessler, G. (2000). Manajemen Sumber Daya Manusia, Edisi Terjemahan, Jakarta: Penerbit PT. Prenhallindo.

Fadjarajani, Siti, dkk. (2020). Metodologi Penelitian Pendekatan Multidisipliner. Gorontalo: Ideas Publishing.

Fathoni, A. R. (2009). Organisasi dan Manajemen Sumber Daya Manusia. Jakarta: Rineka Cipta.

Haekal, T. M, dkk. (2019). Manajemen Sumber Daya Manusia. Gorontalo: Ideas Publishing.

Hill David, Fred R. (2001). Manajemen Strategi: Konsep-konsep. Jakarta: Indeks.

Harun, C. Z. (2009). Manajemen Sumber Daya Manusia.Yogjakarta: Pena Persada.

Hasibuan, M. S. P. (2008). Manajemen sumber daya manusia. Jakarta: Bumi Aksara

Iskandar. (2009). Metode Penelitian Kualitatif. Jakarta: Gaung Persada.

Mahmud. (2011). Metode Penelitian. Bandung: Pustaka Setia.

Marwansyah. (2010). Manajemen Sumber Daya Manusia. Bandung: Alfabeta.

Moleong, L. J. (2010). Metode Penelitian Kualitatif. Bandung: Remaja Rosdakarya.

Nasution, S. (2006). Metode Penelitian Kualitatif. Bandung, Tarsito.

Nisjar, Karhi Winardi. (1997). Manajemen Strategik. Bandung: Mandar Maju Palinggi. 2008. Manajemen Strategik. Jakarta: Salemba Empat.

Notoatmodjo, S. (2009). Pengembangan Sumber Daya Manusia: Jakarta: Rineka Cipta.

Patilima, H. (2011). Metode Penelitian Kualitatif. Bandung: Alfabeta. 


\section{ARTIKEL}

$\overline{\text { Rangkuti, F. (2006). Analisis SWOT Teknik Membedah Kasus Bisnis, cetakan kedua belas. }}$ Jakarta: PT. Gramedia Pustaka Utama.

Rivai, V., \& Sagala, E. J. (2009). Manajemen Sumber Daya Manusia untuk Perusahaan. Jakarata: Rajawali Pers.

Robinson. (2008). Manajemen Strategis: Formulasi, Implementasi dan Pengendalian. Jakarta: Salemba Empat.

Saebani, B. A. (2008). Metode Penelitian. Bandung: Pustaka Setia.

Siagain, S. P. (2012). Manajemen Sumber Daya Manusia. Jakarta: Bumi Aksara.

Sugiyono. (2013). Metode Penelitian Kombinasi. Bandung: Alfabeta.

Suwatno \& Yuniarsih, T. (2013). Manajemen Sumber Daya Manusia. Bandung: Alfabeta.

Tunggal, A. W. (2001). Analisis SWOT, Suatu Pengantar. Jakarta: Harvarindo. 